\title{
Current Drugs with Potential for Treatment of COVID-19: A Literature Review
}

\author{
Md Insiat Islam Rabby \\ Department of Mechanical and Manufacturing Engineering, Universiti Putra Malaysia, Malaysia
}

Received, March 26, 2020; Revised, April 2, 2020; Accepted, April 3, 2020; Published, April 4, 2020.

\begin{abstract}
Purpose: SARS-CoV-2 first emerged in China in December 2019 and rapidly spread worldwide. No vaccine or approved drug is available to eradicate the virus, however, some drugs that are indicated for other afflictions seems to be potentially beneficial to treat the infection albeit without unequivocal evidence. The aim of this article is to review the published background on the effectiveness of these drugs against COVID-19 Methods: A thorough literature search was conducted on recently published studies which have published between January 1 to March 25, 2020. PubMed, Google Scholar and Science Direct databases were searched Results: A total 22 articles were found eligible. 8 discuss about treatment outcomes from their applied drugs during treatment of COVID-19 patients, 4 report laboratory tests, one report animal trial and other 9 articles discuss recommendations and suggestions based on the treatment process and clinical outcomes of other diseases such as malaria, ebola, severe acute respiratory syndrome (SARS) and Middle East respiratory syndrome (MERS). The data and/or recommendations are categorized in 4 classes: (a) anti-viral and anti-inflammatory drugs, (b) anti-malaria drugs, (c) traditional Chinese drugs and (d) other treatments/drugs. Conclusion: All examined treatments, although potentiality effective against COVID-19, need either appropriate drug development or clinical trial to be suitable for clinical use.
\end{abstract}

\section{INTRODUCTION}

The world has experienced various dangerous outbreaks of various intensities such as ebola, cholera, Spanish flu, American seasonal flu. Now we are facing an arguably a more dangerous viral endemic with COVID-19. This severe acute respiratory syndrome coronavirus 2 (SARS-CoV-2), formerly known as the 2019 novel Coronavirus (2019nCoV or COVID-19), is a single-stranded RNA beta-coronavirus whose genome encodes are structural proteins, non-structural proteins and accessory proteins (1). It has globally already infected 413467 people and killed 18,433 people by 25 March, 2020 (2) and the casualties are growing exponentially. In the meantime, only 113453 patients have recovered which is $27.45 \%$ of total affected population (2). The characteristics of the infected population is already published $(3,4)$.

Various treatments have been suggested and applied to control COVIDE-19 based on previous experiences with other viral infections such as malaria, ebola and cholera (6). In addition, a systematic review of the effect of chloroquine on COVID-19 infection has appeared (5). However, these treatments have resulted in controversy as are not based on data generated from direct conventional clinical trials albeit, a list of ongoing registered clinical trials have been reported by Zhang et al (7). Herein, a thorough literature review on these treatments are presented.

\section{METHODS}

\section{Search and selection strategy}

A literature search was conducted to cover the period January 1-March 25, 2020. PubMed, Google Scholar and Science Direct databases were selected as search strings. EndNote X 9.0 software was used to exclude duplicates from searched data. "Treatment for COVID-19" AND "Vaccine, Anti-viral drugs, Antimalaria drugs, Traditional Chinese Medicine for COVID-19" such keywords were using in search string without considering any restriction of language to identify potential published studies. Moreover, missing studies were identified by checking the reference list of the selected articles.

Corresponding Author: Md Insiat Islam Rabby; Department of Mechanical and Manufacturing Engineering, Universiti Putra Malaysia, Malaysia; insiatislam8@gmail.com. 
The studies which describe about the current treatment process and drugs for COVID-19 infection were selected to conduct this study wherein some editorial and letter to editor were also included which mainly recommended some drugs based on the treatment process of previous epidemic viruses such as malaria, ebola, severe acute respiratory syndrome (SARS) and middle east respiratory syndrome (MERS). Meanwhile, studies which (a) duplicate publications (b) full articles not available (c) literature reviews and (d) do not provided sufficient information or support regarding their recommendation of their proposed drugs or treatment process were excluded. However, few articles which are still in press also selected for this analysis to meet the aim of this study. The steps taken to conduct the present search are presented in Figure 1.

\section{Data extraction and analysis}

To conduct this study the author, date, name and category of the drugs, effectiveness of the drugs, reason for effectiveness, the type of observation (hospital/ clinical trial/ animal trial/ laboratory) were recorded. For the case studies and laboratory tests, when the drugs applied, the size of the dose, sex and age of patients were noted.

\section{RESULTS}

A total of 1153 articles initially identified. After removing duplicates, checking title, abstract and full text 22 were found eligible based on the predetermined exclusion and inclusion criteria for this study. From this 22 articles, 8 were case reports which reported treatment of COVID-19 patients, 4 reported laboratory tests, one reported animal trial and others 9 reported recommendations and suggestions based on experience involving the use of drugs in other viral infection; i.e., malaria, ebola, severe acute respiratory syndrome (SARS) and middle east respiratory syndrome (MERS). These studies are summarized in Table 1. Based on the information and authors comments, the drugs are categorized in 4 classes- (a) Anti-viral and Antiinflammable drugs, (b) Anti-malaria drugs, (c) Traditional Chinese drugs (TCM) and (d) other treatments/drugs.

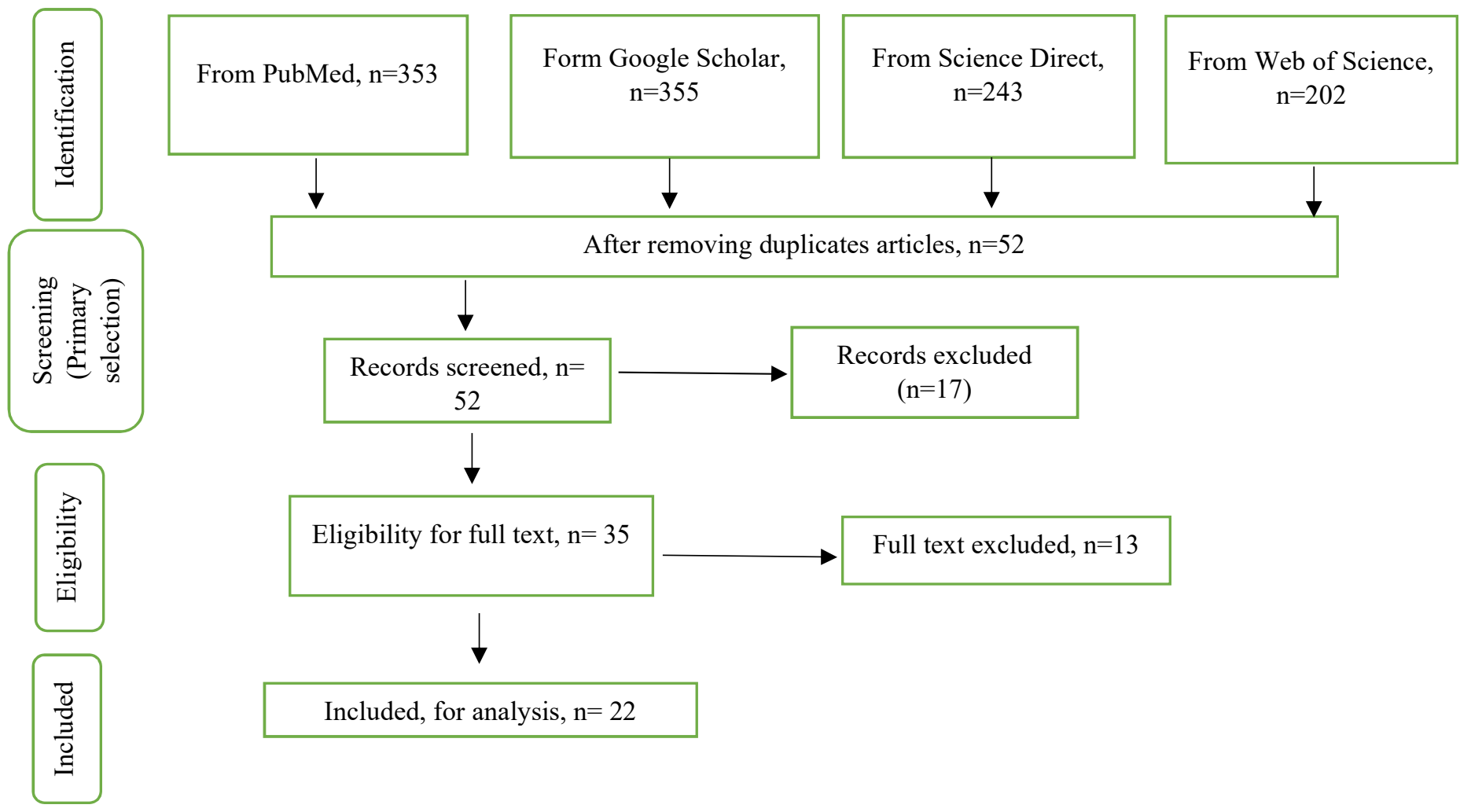

Figure 1. Summary of study selection design 
Table 1. Summary of findings reported in selected articles

\begin{tabular}{|c|c|c|c|c|}
\hline Study & $\begin{array}{l}\text { Drugs applied or } \\
\text { suggested }\end{array}$ & Type of report & Outcomes & drugs Category \\
\hline $\begin{array}{l}\text { Wen et al } \\
\text { (8) }\end{array}$ & $\begin{array}{l}\text { Glucocorticoids, IL-6 } \\
\text { antagonist, JAK } \\
\text { inhibitors and } \\
\text { chloroquine/ } \\
\text { hydroxychloroquine }\end{array}$ & Clinical observation & Improved clinical outcome & $\begin{array}{l}\text { Anti-malarial and anti- } \\
\text { inflammatory }\end{array}$ \\
\hline $\begin{array}{l}\text { Gautret et } \\
\text { al (9) }\end{array}$ & $\begin{array}{l}\text { Azithromycin plus } \\
\text { hydroxychloroquine. } \\
\text { for } 6 \text { days }\end{array}$ & $\begin{array}{l}\text { Open label non- } \\
\text { randomized clinical trial } \\
\text { with } 6 \text { COVID-19 positive } \\
\text { patients }\end{array}$ & $\begin{array}{l}\text { An Improved efficacy to } \\
\text { eradicate the virus }\end{array}$ & $\begin{array}{l}\text { Anti-viral plus anti- } \\
\text { inflammatory }\end{array}$ \\
\hline $\begin{array}{l}\text { Runfeng et } \\
\text { al (10) }\end{array}$ & Lianhuaqingwen & $\begin{array}{l}\text { Laboratory test using } \\
\text { African green monkey } \\
\text { kidney epithelial (Vero } \\
\text { E6) cells and the human } \\
\text { hepatocellular carcinoma } \\
\text { (Huh-7) cells }\end{array}$ & $\begin{array}{l}\text { Protection against COVID-19 } \\
\text { virus attract }\end{array}$ & $\begin{array}{l}\text { Traditional Chinese } \\
\text { Medicine }\end{array}$ \\
\hline $\begin{array}{l}\text { Liu et al } \\
\text { (11) }\end{array}$ & $\begin{array}{l}\text { Hydroxychloroquine } \\
\text { and chloroquine }\end{array}$ & $\begin{array}{l}\text { in vitro cytotoxicity and } \\
\text { antiviral tests }\end{array}$ & $\begin{array}{l}\text { HCQ a safe and effective } \\
\text { treatment against COVID-19 }\end{array}$ & $\begin{array}{l}\text { Anti-malarial, anti- } \\
\text { inflammatory }\end{array}$ \\
\hline $\begin{array}{l}\text { Zahra et al } \\
\text { (12) }\end{array}$ & $\begin{array}{l}\text { Hydroxychloroquine } \\
\text { chloroquine and } \\
\text { several other } \\
\text { therapeutic agents }\end{array}$ & Opinion paper & $\begin{array}{l}\text { Hydroxychloroquine is preferred } \\
\text { to over chloroquine as they are } \\
\text { equally effective as antimalarial } \\
\text { drug but the former has a more } \\
\text { favorable safety profile }\end{array}$ & $\begin{array}{l}\text { Anti-malarial, Anti-viral and } \\
\text { others }\end{array}$ \\
\hline
\end{tabular}

\begin{tabular}{|c|c|c|c|c|}
\hline $\begin{array}{l}\text { Cai et al } \\
\text { (13) }\end{array}$ & $\begin{array}{l}\text { Favipiravir }(\mathrm{n}=35) \text { vs } \\
\text { control (lopinavir or } \\
\text { ritonavir } \mathrm{n}=45) \text {. All } \\
\text { received interferon } \\
\text { alfa }\end{array}$ & Open label clinical trial & $\begin{array}{l}\text { Significantly shorter COVID-19 } \\
\text { clearance and improved chest } \\
\text { imaging with favipiravir as } \\
\text { compared with control }\end{array}$ & Anti-viral \\
\hline $\begin{array}{l}\text { Wu et al } \\
(14)\end{array}$ & $\begin{array}{l}\text { Janus kinase } 2 \\
\text { (JAK2) } \\
\text { Inhibitor fedratinib }\end{array}$ & $\begin{array}{l}\text { in vitro murine } \mathrm{TH} 17 \text { cell } \\
\text { study }\end{array}$ & $\begin{array}{l}\text { Fedratinib suppresses } \\
\text { expression of IL17, IL } 22 \text { and } \\
\text { L23 with no effect on IL } 22 \text {. } \\
\text { Thus the drug may be beneficial } \\
\text { in reducing cytokine storm } \\
\text { associated with COVID-19 } \\
\text { infection }\end{array}$ & Anti-inflammatory \\
\hline $\begin{array}{l}\text { Yao et al } \\
\text { (15) }\end{array}$ & $\begin{array}{l}\text { Chloroquine and } \\
\text { hydroxychloroquine }\end{array}$ & $\begin{array}{l}\text { in vitro infected vero } \\
\text { cells }\end{array}$ & $\begin{array}{l}\text { Substantial lower EC50 for } \\
\text { hydroxychloroquine vs } \\
\text { chloroquine in inhibiting } \\
\text { COVId-19 }\end{array}$ & Anti-malarial \\
\hline $\begin{array}{l}\text { Tang et al } \\
\text { (16) }\end{array}$ & $\begin{array}{l}\text { Lopinavir plus } \\
\text { ritonavir }\end{array}$ & $\begin{array}{l}\text { Case study; COVID-19- } \\
\text { induced pneumonia on a } \\
\text { hemodialysis patient }\end{array}$ & $\begin{array}{l}\text { Improved clinical symptoms. } \\
\text { Inconclusive whether the } \\
\text { antiviral therapy was effective. }\end{array}$ & Antiviral \\
\hline $\begin{array}{l}\text { Fan et al } \\
(17)\end{array}$ & $\begin{array}{l}\text { Cepharanthine, } \\
\text { selamectin and } \\
\text { mefloquine }\end{array}$ & $\begin{array}{l}\text { Cell culture and pangolin } \\
\text { coronavirus modelling }\end{array}$ & $\begin{array}{l}\text { Complete inhibition of } \\
\text { cytopathic effects in cell culture } \\
\text { by all three drugs. }\end{array}$ & $\begin{array}{l}\text { Anti-inflammatory/ } \\
\text { antineoplastic, anti-parasitic, }\end{array}$ \\
\hline $\begin{array}{l}\text { Ren et al } \\
\text { (18) }\end{array}$ & $\begin{array}{l}\text { Qingfei paidu } \\
\text { decoction, }\end{array}$ & A single case study & $\begin{array}{l}\text { Controlling of COVID-19 } \\
\text { symptoms. . }\end{array}$ & $\begin{array}{l}\text { Traditional Chinese } \\
\text { Medicine }\end{array}$ \\
\hline
\end{tabular}


Table 1. Continued...

\begin{tabular}{lllll}
\hline $\begin{array}{l}\text { Stebbing et } \\
\text { al (19) }\end{array}$ & $\begin{array}{l}\text { Baricitinib, } \\
\text { fedratinib, and } \\
\text { ruxolitinib }\end{array}$ & $\begin{array}{l}\text { in silico artificial } \\
\text { intelligence prediction }\end{array}$ & $\begin{array}{l}\text { Prediction of significant } \\
\text { beneficial effects in the } \\
\text { treatment of COVID-19 }\end{array}$ & $\begin{array}{l}\text { JAK inhibitors Anti- } \\
\text { inflammatory agents }\end{array}$ \\
\hline $\begin{array}{l}\text { Gordon et } \\
\text { al (20) }\end{array}$ & Remdesivir & $\begin{array}{l}\text { in vitro co-expression of } \\
\text { MERS-CoV nonstructural } \\
\text { proteins in insect cells }\end{array}$ & $\begin{array}{l}\text { The proteins form a complex } \\
\text { and likely delay RNA chain } \\
\text { termination. Also nucleotides } \\
\text { may protect the inhibitor from } \\
\text { excision. These may explain the } \\
\text { high potency of remdesivir }\end{array}$ & $\begin{array}{l}\text { Broad spectrum RNA } \\
\text { polymerase inhibitor anti- }\end{array}$ \\
& & $\begin{array}{l}\text { against RNA viruses in cell- } \\
\text { based assays. }\end{array}$ &
\end{tabular}

\begin{tabular}{lll}
\hline $\begin{array}{l}\text { Nguyen et } \\
\text { al (21) }\end{array}$ & CRISPR/Cas13d & in vitro tests \\
& strategy for treating & \\
& 2019-nCov(SARS- \\
& CoV-2) virus \\
& infection
\end{tabular}
They proposed that CRISPR/Cas13d system has straightforward and flexible potentiality for RNA virus treatment and prevention which may be used for the treatment of COVID-19

\section{Others treatment/drugs}

\begin{tabular}{|c|c|c|c|c|}
\hline $\begin{array}{l}\text { Guangdi \& } \\
\text { De Clercq } \\
\text { (1) }\end{array}$ & $\begin{array}{l}\text { Remdesivir, } \\
\text { umifenovir, } \\
\text { oseltamivir and } \\
\text { ASC09F, around } 50 \\
\text { existing MERS } \\
\text { and/or SARS } \\
\text { inhibitors, such as the } \\
\text { protease inhibitors } \\
\text { GC813, galidesivir, } \\
\text { compound 3k, the } \\
\text { nucleoside analogue } \\
\text { pyrazofurin and the } \\
\text { helicase inhibitor } \\
\text { SSYA10-001 }\end{array}$ & Opinion & $\begin{array}{l}\text { The authors claimed that these } \\
\text { inhibitors have appropriate } \\
\text { potential biocontainment } \\
\text { capability against covid- } 19 \text {. }\end{array}$ & Anti-viral \\
\hline $\begin{array}{l}\text { Sun Meli et } \\
\text { al (22) }\end{array}$ & $\begin{array}{l}\text { Renin-Angiotensin } \\
\text { System (RAS) } \\
\text { inhibitors }\end{array}$ & opinion & $\begin{array}{l}\text { Authors opine that RAS } \\
\text { inhibitors have the ability to } \\
\text { alleviate several symptoms of } \\
\text { acute severe pneumonia and also } \\
\text { relieve respiratory failure ACEI } \\
\text { and AT1R inhibition }\end{array}$ & Others treatment/drugs \\
\hline $\begin{array}{l}\text { Lim et al } \\
(23)\end{array}$ & Lopinavir/ritonavirA & Single patient clinical case & $\begin{array}{l}\text { Lopinavir/ritonavir significantly } \\
\text { reduced COVID-19 load }\end{array}$ & Anti-viral \\
\hline Kruse (24) & $\begin{array}{l}\text { Angiotensin- } \\
\text { converting enzyme } 2 \text {, } \\
\text { fused to an } \\
\text { immunoglobulin Fc } \\
\text { domain. }\end{array}$ & Opinion & $\begin{array}{l}\text { ACE2-Fc has the potentiality to } \\
\text { be the neutralizing antibody that } \\
\text { can be used for the treatment of } \\
\text { COVID-19 }\end{array}$ & Others treatment/drugs \\
\hline $\begin{array}{l}\text { Wang } M . \\
\text { et al }(25)\end{array}$ & $\begin{array}{l}\text { Remdesivir, ribavirin, } \\
\text { penciclovir, } \\
\text { nitazoxanide, } \\
\text { nafamostat, } \\
\text { remdesivir favipiravir } \\
\text { and chloroquine }\end{array}$ & $\begin{array}{l}\text { In vitro test using COVIC- } \\
19 \text { infected Vero E6 cells }\end{array}$ & $\begin{array}{l}\text { All tested drugs were effective } \\
\text { with Remdesivir and, } \\
\text { chloroquine having most potent } \\
\text { activities. }\end{array}$ & Anti-viral and Anti-malarial \\
\hline
\end{tabular}


Table 1. Continued...

\begin{tabular}{lllll}
\hline $\begin{array}{l}\text { Wang, Z. et } \\
\text { al (26) }\end{array}$ & $\begin{array}{l}\text { Lopinavir/ritonavir, } \\
\text { arbidol, and Shufeng } \\
\text { Jiedu (Chinese med) }\end{array}$ & Case report of 4 patients & The treatments were effective. & Anti-viral and Anti-malarial \\
\hline $\begin{array}{l}\text { Holshue et } \\
\text { al (27) }\end{array}$ & Remdesivir & Single patient case report & Patient recovered. & Anti-viral \\
\hline $\begin{array}{l}\text { H.L. Zhang } \\
\text { and Y.X. } \\
\text { Zhu (28) }\end{array}$ & $\begin{array}{l}\text { Traditional Chinese } \\
\text { Medicine }\end{array}$ & $\begin{array}{l}\text { A single patient case } \\
\text { report }\end{array}$ & Patient recovered. & $\begin{array}{l}\text { Traditional Chinese } \\
\text { Medicine }\end{array}$ \\
\hline
\end{tabular}

\section{DISCUSSION and CONCLUSION}

This literature review and analysis was conducted based on recently published studies on treatment of COVID-19 diseases.

This review clearly demonstrates that the available data are not sufficient to suggest any treatment for eradication of COVID-19 to be used at the clinical level. All human studies lack comparative data so that it remains unclear whether the patient recovered because of the use of particular drug or the general clinical care received. Most in vitro studies, however, are suggestive of potential beneficial effects although the data are too preliminary to be used as rationale for clinical use.

The motivation for the use of antiviral drugs to treat COVID-19 infection, a viral disease, is obvious. However, the interest in the use of antimalarial drugs stems in the unexpected finding of beneficial effect of hydroxychloroquine in the treatment of HIV patients (29). Nevertheless, the beneficial effects of chloroquines in patients with COVID-19 needs to be tested through appropriately conducted clinical trials. However, a point that needs careful attention is the safety profile of these two antimalarial drugs. The toxicity of chloroquine is well-acknowledged, but it is often ignored that hydroxychloroquine is a relatively safe drug being used by a vast population of patients with early rheumatoid arthritis (30). Therefore, the focus of the studies may need to be on hydroxychloroquine instead of more toxic chloroquine.

\section{LIMITATIONS}

This literature review has few limitation. For inclusion, very few studies were available and most of them were from a single geographic location. For better understanding of the genetic and environmental effects, studies involving patients from other geographical regions are needed. Additionally, detailed information of patients, clinical and laboratory outcomes of recommended drugs were unavailable for most of the cases included in this review.

\section{CONFLICTS OF INTEREST}

No conflicts of interest.

\section{FUNDING SOURCE}

Author did not receive any fund for this study.

\section{REFERENCE}

1. Guangdi Li \& Erik De Clercq. Therapeutic options for the 2019 novel coronavirus (2019-nCoV). Nature Reviews Drug Discovery 19, 149-150. https://doi: 10.1038/d41753-020-00016-0.

2. Novel Coronavirus (COVID-19) Situation by World Health Organization, (25 March, 2020) https://experience.arcgis.com/experience/685d0ace5 21648f8a5beeeee1b9125cd

3. Rodriguez-Morales AJ, Cardona-Ospina JA, Gutiérrez- Ocampo Estefaní, Villamizar-Peña R, Holguin-Rivera Y, Escalera-Antezana JP, AlvaradoArnez LE, Bonilla-Aldana DK, Franco-Paredes C, Henao-Martinez AndréF, Paniz-Mondolfi A, LagosGrisales GJ, Ramírez-Vallejo E, Suárez JA, Zambrano LI, Villamil-Gómez WE, Balbin-Ramon GJ, Rabaan AA, Harapan H, Dhama K, Nishiura H, Kataoka H, Ahmad T, Sah R. Clinical, laboratory and imaging features of COVID-19: A systematic review and meta-analysis, Travel Medicine and Infectious Disease doi:https://doi.org/10.1016/j.tmaid.2020.101623.

4. Sohrabi C, Alsafi Z, O'Neill N, Khan M, Kerwan A, Al-Jabir A, Iosifidis C, Agha R. World Health Organization declares Global Emergency: A review 
of the 2019 Novel Coronavirus (COVID-19), International Journal of Surgery, 2020. https://doi.org/10.1016/j.ijsu.2020.02.034.

5. Cortegiani, A., Ingoglia, G., Ippolito, M., Giarratano, A., \& Einav, S. A systematic review on the efficacy and safety of chloroquine for the treatment of COVID-19. Journal of Critical Care. (2020). doi:10.1016/j.jcrc.2020.03.005.

6. Hongzhou Lu. Drug treatment options for the 2019new coronavirus (2019-nCoV). Bio Science Trends. (2020). doi:10.5582/bst.2020.01020.

7. Zhang Q, Wang Y, Qi C, Shen L, Li J. Clinical trial analysis of 2019-nCoV therapy registered in China. J Med Virol. 26 February 2020; 1-6. https://doi.org/10.1002/jmv.25733.

8. Wen Zhang, Y. Zhao, F. Zhang, et al. The use of antiinflammatory drugs in the treatment of people with severe corona virus disease 2019 (COVID-19): The experience of clinical immunologists from China. Clinical Immunology, (25 March 2020), 108393. https://doi.org/10.1016/j.clim.2020.108393.

9. Gautret Philippe, Jean-Christophe Lagierac, Philippe Parola, Van Thuan Hoang, Line Meddeb, Morgane Mailhe, Barbara Doudier, Johan Courjon, Valérie Giordanengo, Vera Esteves Vieira, Hervé Tissot Dupont, Stéphane Honoré, Philippe Colson, Eric Chabrière Bernard La Scola, Jean-Marc Rolain, Philippe Brouqui, Didier Raoult. Hydroxychloroquine and azithromycin as a treatment of COVID-19: results of an open-label nonrandomized clinical trial," International Journal of Antimicrobial Agents, (20 March 2020), 105949. https://doi.org/10.1016/j.ijantimicag.2020.105949

10. Runfeng L, Yunlong H, Jicheng H, Weiqi P, Qinhai M, Yongxia S, Chufang L, Jin Z, Zhenhua J, Haiming J, Kui Z, Shuxiang H, Jun D, Xiaobo L, Xiaotao H, Lin W, Nanshan Z, Zifeng Y. Lianhuaqingwen exerts anti-viral and anti-inflammatory activity against novel coronavirus (SARS-CoV-2). Pharmacological Research (2020), doi: https://doi.org/10.1016/j.phrs.2020.104761.

11. Liu, J., Cao, R., Xu, M. et al. Hydroxychloroquine, a less toxic derivative of chloroquine, is effective in inhibiting SARS-CoV-2 infection in vitro. Cell Discov 6, 16 (2020). https://doi.org/10.1038/s41421020-0156-0.

12. Zahra Sahraei Pharm. D, BCPS, Minoosh Shabani MD , Shervin Shokouhi MD, MPH , Ali Saffaei Pharm. D. Aminoquinolines against Coronavirus Disease 2019 (COVID-19): Chloroquine or Hydroxychloroquine. International Journal of Antimicrobial Agents (17 March 2020), 105945, doi: https://doi.org/10.1016/j.ijantimicag.2020.105945

13. Cai Q., M. Yang, D. Liu, J. Chen, D. Shu, J. Xia, X. Liao, Y. Gu, Q. Cai, Y. Yang, C.Shen, X. Li, L. Peng, D. Huang, J. Zhang, S. Zhang, F. Wang, J. Liu, L. Chen, S. Chen, Z. Wang, Z. Zhang, R.Cao, W. Zhong,
Y. Liu, L. Liu. Experimental Treatment with Favipiravir for COVID-19: An Open-Label Control Study, Engineering (18 March, 2020).https://doi.org/10.1016/j.eng.2020.03.007

14. Wu, D., \& Yang, X. O. (2020). TH17 Responses in Cytokine Storm of COVID-19: An Emerging Target of JAK2 Inhibitor Fedratinib. Journal of Microbiology, Immunology and Infection (11 March 2020). doi:10.1016/j.jmii.2020.03.005.

15. Yao, X., Ye, F., Zhang, M., Cui, C., Huang, B., Niu, P., Liu, D. In Vitro Antiviral Activity and Projection of Optimized Dosing Design of Hydroxychloroquine for the Treatment of Severe Acute Respiratory Syndrome Coronavirus 2 (SARS-CoV-2). Clinical Infectious Diseases. 10 march 2020. doi:10.1093/cid/ciaa237.

16. Tang B, Li S, Xiong Y, Tian M, Yu J, Xu L, Zhang L, Li Z, Ma J, Wen F, Feng Z, Liang X, Shi W, Liu S. Coronavirus Disease 2019 (COVID-19) Pneumonia in a Hemodialysis Patient. Kidney Medicine (2020), doi:https://doi.org/10.1016/j.xkme.2020.03.001.

17. Fan, Hua-Hao; Wang, Li-Qin; Liu, Wen-Li; An, Xiao-Ping; Liu, Zhen-Dong; He, Xiao-Qi; Song, LiHua; Tong, Yi-Gang. Repurposing of clinically approved drugs for treatment of coronavirus disease 2019 in a 2019-novel coronavirus (2019-nCoV) related coronavirus model. Chinese Medical Journal: March 2020, doi:10.1097/CM9.0000000000000797.

18. Ren J-ling, Zhang A-Hua, Wang X-Jun. Traditional Chinese Medicine for COVID-19 Treatment. Pharmacological Research, 155 (2020) 104743, doi: 10.1016/j.phrs.2020.104743.

19. Stebbing Justin, Anne Phelan, Ivan Griffin, Catherine Tucker, Olly Oechsle, Dan Smith, Peter Richardson. COVID-19: combining antiviral and antiinflammatory treatments, Lancet Infect Dis, February 27, 2020 DOI:https://doi.org/10.1016/S14733099(20)30132-8

20. Gordon, C. J., Tchesnokov, E. P., Feng, J. Y., Porter, D. P., \& Gotte, M. The antiviral compound remdesivir potently inhibits RNA-dependent RNA polymerase from Middle East respiratory syndrome coronavirus. Journal of Biological Chemistry, (2020 Feb 24). pii: jbc.AC120.013056. doi: 10.1074/jbc.AC120.013056.

21. Nguyen, T.M., Zhang, Y. \& Pandolfi, P.P. Virus against virus: a potential treatment for 2019-nCov (SARS-CoV-2) and other RNA viruses. Cell Res 30, 189-190(2020). https://doi.org/10.1038/s41422-020$\underline{0290-0}$

22. Sun Meili, Yang Jianmin, Sun Yuping, et al. RAS inhibitor is one of the possible options for the treatment of new coronavirus pneumonia [J / OL]. Chinese Journal of Tuberculosis and Respiratory 
Diseases, 2020, 43 (2020-02-16). DOI: $10.3760 /$ cma.j.jssn.1001-0939.2020.0014.

23. Lim, J., Jeon, S., Shin, H.-Y., Kim, M. J., Seong, Y. M., Lee, W. J., Park, S.-J. (2020). Case of the Index Patient Who Caused Tertiary Transmission of Coronavirus Disease 2019 in Korea: the Application of Lopinavir/Ritonavir for the Treatment of COVID19 Pneumonia Monitored by Quantitative RT-PCR. Journal of Korean Medical Science, 35(6). doi:10.3346/jkms.2020.35.e79.

24. Kruse Robert L. Therapeutic strategies in an outbreak scenario to treat the novel coronavirus originating in Wuhan, China. F1000 Research (2020), 9:72 (https://doi.org/10.12688/f1000research.22211.2)

25. Wang, M., Cao, R., Zhang, L. et al. Remdesivir and chloroquine effectively inhibit the recently emerged novel coronavirus (2019-nCoV) in vitro. Cell Res 30, 269-271 (2020). https://doi.org/10.1038/s41422020-0282-0

26. Wang, Z., Chen, X., Lu, Y., Chen, F., \& Zhang, W. (2020). Clinical characteristics and therapeutic procedure for four cases with 2019 novel coronavirus pneumonia receiving combined Chinese and Western medicine treatment. Bio Science Trends. doi:10.5582/bst.2020.01030

27. Holshue, M. L. et al. First case of 2019 novel coronavirus in the United States. N. Engl. J. Med. (January 31, 2020). https://doi.org/10.1056/NEJMoa2001191.

28. H.L. Zhang, Y.X. Zhu. One highly suspected case of novel coronavirus pneumonia treated by Integrated Traditional Chinese and Western medicine and nucleic acid analysis. Tianjin Journal of Traditional Chinese Medicine. http://kns.cnki.net/kcms/ detail/12.1349.R.20200227.0909.004.html.

29. Carroll, M. B., Fields, J., \& Clerc, P. Rheumatoid arthritis in patients with HIV: management challenges. Open Access Rheumatology: Research and Reviews, (2016):8 51-59. doi:10.2147/oarrr.s87312.

30. The HERA study. A randomized trial of hydroxychloroquine in early rheumatoid arthritis: The American Journal of Medicine, (1995). 98(2), 156-168. doi:10.1016/s0002-9343(99)80399-4 